\title{
Strategi Komando Resor Militer 043/ Garuda Hitam Dalam Penanggulangan Bencana Alam di Propinsi Lampung
}

\section{Strategy of Military Resort Command 043/Garuda Hitam for Natural Disaster Management in Lampung Province}

\author{
Agung Priambodo 1) 2)*, Nrangwesthi Widyaningrum ${ }^{1)}$ \& \\ Hayatul Khairul Rahmat1)
}

1) Program Studi Magister Manajemen Bencana, Fakultas Keamanan Nasional, Universitas Pertahanan, Indonesia

2) Badan Nasional Pencarian dan Pertolongan (Badan SAR Nasional), Indonesia

Diterima: 27 Februari 2020; Disetujui: 08 April 2020; Diterbitkan: 01 Juli 2020

\begin{abstract}
Abstrak
Peran Komando Resor Militer (Korem) dalam penanggulangan bencana merupakan bentuk implementasi dari tugas TNI yaitu tugas Operasi Militer Selain Perang (OMSP) sesuai amanat Undang-Undang Republik Indonesia Nomor 32 Tahun 2004 tentang Tentara Nasional Indonesia (TNI). Pelaksanaan penanggulangan bencana di daerah yang dilakukan Komando Resor Militer melibatkan Instansi Pemerintah dan stake holder lainnya sehingga diperlukan koordinasi dan komunikasi yang baik agar tercipta sinergitas antara Komando Resor Militer, instansi pemerintah dan stakeholder dalam penanggulangan bencana. Terkait peran Komando Resor Militer tersebut, penelitian ini dilaksanakan dengan tujuan untuk mengetahui Strategi Komando Resor Militer 043/ Garuda Hitam dalam penanggulangan bencana di Propinsi Lampung. Penelitian ini menggunakan metode kualitatif dengan pendekatan studi kasus. Selain itu, peneliti melakukan wawancara, observasi dan studi dokumentasi untuk mengumpulkan data dan dianalisis. Hasil dari penelitian ini berupa strategi Komando Resor Militer 043/ Garuda Hitam dalam penanggulangan bencana yaitu dengan melakukan koordinasi dan komunikasi dengan instansi pemerintah dan stakeholder lainnya serta memaksimalkan kegiatan Pembinaan Teritorial (Binter) yang menjadi salah satu tugas Komando Hitam 043/ Garuda Hitam di Propinsi Lampung.

Kata Kunci: Strategi, Koordinasi, Komunikasi, Pembinaan Teritorial.
\end{abstract}

\begin{abstract}
The role of the Military Resort Command in disaster management is a form of implementation of the Indonesian Armed Forces' tasks, namely the task of Military Operations Other Than War (OMSP) in accordance with the mandate of Law Number 32 of 2004 concerning the Indonesian Armed Forces (TNI). Disaster management in the regions carried out by the the Military Resort Command involvement of government agencies and other stakeholders. Between the the Military Resort Command, government agencies and stakeholders in disaster management. Related to the role of the the Military Resort Command, this research was conducted with the aim to study the the Military Resort Command 043/ Garuda Hitam's Strategy for disaster management in Lampung Province. This research uses a qualitative method using case studies. In addition, researchers conducted interviews, observations and documentation studies to collect data and analyzed. The Military Resort Command 043/ Garuda Hitam in disaster management is by coordinating and communicating with government agencies and other stakeholders as well as facilitating Territorial Development (Binter) activities which are one of the tasks of the Military Resort Command 043/ Garuda Hitam in Lampung Province.
\end{abstract}

Keywords: Strategy, Coordination, Communcation, Territorial Development.

How to Cite: Priambodo, A., Widyaningrum, N. \& Rahmat, H. K. (2020). Strategi Komando Resor Militer 043/ Garuda Hitam dalam Penanggulangan Bencana Alam di Provinsi Lampung. PERSPEKTIF, 9 (2): 307-313. 


\section{PENDAHULUAN}

Salah satu keunikan yang dimiliki oleh negara Indonesia adalah letaknya yang berada di lintasan garis khatulistiwa. Posisi ini yang menyebabkan Indonesia memiliki iklim tropis dengan 2 (dua) musim yaitu panas dan hujan. Indonesia juga dikelilingi oleh Cincin Api (Ring of Fire) berupa gugusan pegunungan aktif yang sewaktu-waktu dapat meletus dan mengeluarkan material dari dalam perut bumi. Selain itu, Indonesia memiliki 295 sumber gempa yang tersebar di seluruh wilayah di Indonesia sehingga Indonesia menjadi wilayah yang sangat rawan bencana (Pusat Studi Gempa Nasional, 2017).

Seiring berjalannya waktu dengan kebutuhan manusia yang semakin meningkat, ketergantungan manusia dengan potensi alam yang ada menjadi penyebab dari kerusakan alam jika tidak diperlakukan dengan bijak. Tanpa disadari kerusakan alam ini memicu terjadinya bencana alam yang mengakibatkan kerugian baik materil maupun imateriil. Bencana alam yang terjadi datang silih berganti di berbagai daerah. Berikut adalah gambar yang menyajikan tentang bencana alam yang terjadi di Indonesia selama tahun 2019:

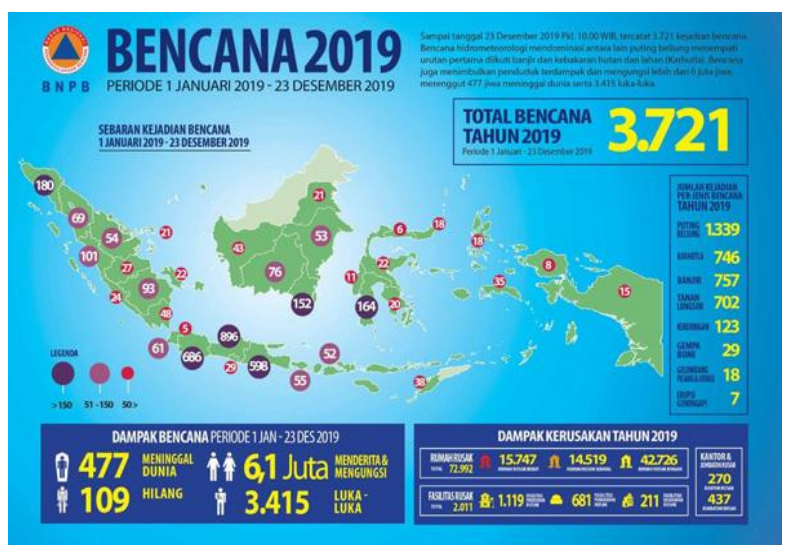

Gambar 1. Kejadian Bencana Selama 2019

Dalam menghadapi bencana yang terjadi di Indonesia, dibutuhkan peran aktif semua unsur baik Pemerintah, masyarakat maupun dunia usaha. Masing-masing unsur tersebut memiliki tanggung jawab untuk meminimalisir kerugian baik materil maupun immateriil. Peran aktif unsur-unsur tersebut menjadi kekuatan tersendiri dalam pelaksanaan penanggulangan bencana. Unsur-unsur yang terlibat mempunyai tugas dan fungsi tersendiri dalam penanggulangan bencana.
Tugas dan fungsi tersebut harus dapat diintegrasikan sesuai dengan jenis bencana yang terjadi. Salah satu unsur penting dalam penanggulangan bencana adalah Tentara Nasional Indonesia (TNI).

Peran TNI dalam penanggulangan bencana merupakan bentuk implementasi dari tugas TNI yaitu tugas Operasi Militer Selain Perang (OMSP) yang telah diamanatkan di dalam Undang-Undang Republik Indonesia Nomor 34 Tahun 2004 (Patria, 2013). TNI dengan militansi anggota dan jumlah cukup banyak yang tersebar di seluruh wilayah Indonesia memiliki peran yang sangat penting dalam penanggulangan bencana di daerah. Aspek komando dan pengendalian pada unsur TNI menjadi kekuatan khusus yang dimiliki TNI sehingga pada penanggulangan bencana dapat bergerak dengan cepat dan terstruktur. Peran TNI di daerah dilaksanakan oleh satuan yang ada di tiap Provinsi yaitu Komando Resor Militer (Korem).

Peran TNI yang dilaksanakan oleh Korem harus dapat bersinergi dengan Pemerintah daerah dalam menanggulangi bencana yang terjadi di daerah. Pemerintah Daerah dalam hal ini adalah BPBD sebagai unsur pelaksana, komando, dan pengendalian bencana. Selain itu, dalam pelaksanaan penanggulangan bencana, Komando Resor Militer juga melakukan komunikasi dan koordinasi kepada semua stakeholder yang terlibat antara lain Kepolisian Republik Indonesia, Badan Nasional Pencarian dan Pertolongan, organisasi masyarakat, dunia usaha, dan sebagainya. Maka dari itu, diperlukan strategi dalam penanggulangan bencana agar penanganan bencana dapat dilakukan dengan efektif dan efisien. Strategi yang dibuat Komando Resor Militer 043/ Garuda Hitam dalam penanggulangan bencana alam di Provinsi Lampung menjadi evaluasi tersendiri ketika menghadapi bencana alam Tsunami yang terjadi pada akhir tahun 2018 yang lalu. Maka dari itu, penelitian ini mengungkapkan bagaimana strategi Komando Resor Militer 043/ Garuda Hitam dalam penanggulangan bencana alam yang ada di Provinsi Lampung.

\section{METODE PENELITIAN}

Metode penelitian yang digunakan pada penelitian ini adalah kualitatif dengan pendekatan studi kasus. Menurut Bogdan dan 
Biklen (dalam Syamsudin, 2009), studi kasus merupakan pengujian secara rinci terhadap satu latar atau satu orang subjek atau satu tempat penyimpanan dokumen atau satu peristiwa tertentu. Sementara itu, Surachman (dalam Syamsudin, 2009) membatasi pendekatan studi kasus sebagai suatu pendekatan dengan memusatkan perhatian pada satu kasus secara intensif dan rinci. Tempat penelitian ini dilakukan di Komando Resor Militer 043/ Garuda Hitam yang berada di Provinsi Lampung di bawah kendali Kodam II/Sriwijaya. Markas Korem 043/Garuda Hitam beralamat di Jalan Teuku Umar Nomor 85, Penengahan, Kecamatan Tanjung Karang Pusat, Kota Bandar Lampung, Lampung 35112.

Untuk mengetahui strategi Komando Resor Militer 043/ Garuda Hitam dalam penanggulangan bencana, peneliti melakukan pengumpulan data dengan teknik triangulasi sumber data. Triangulasi Sumber Data yaitu menggali kebenaran informai melalui berbagai metode dan sumber data.

Sumber data yang diperoleh melalui penelitian ini antara lain:

1. Wawancara adalah percakapan dengan maksud tertentu. Percakapan ini dilakukan oleh dua pihak, yaitu pewawancara yang memberikan pertanyaan dan pihak yang diwawancarai yaitu pihak yang memberikan jawaban atas pertanyaan itu (Moleong, 2000). Wawancara yang digunakan dalam penelitian ini yaitu wawancara yang semi terstruktur. Hal ini bertujuan untuk mendapatkan informasi yang lebih jelas dan mendalam mengenai suatu permasalahan yang diteliti dan lebih bebas dalam pelaksanaan wawancara dibandingkan dengan wawancara terstruktur.

2. Observasi/ pengamatan dapat mengoptimalkan kemampuan peneliti baik dari segi motif, kepercayaan, perhatian, perilaku tidak sadar, kebiasaan, dan lain sebagainya (Moleong, 2000). Observasi dilakukan peneliti untuk memberi keyakinan pada data-data primer berupa situasi sosial atau peristiwa tertentu, tempat maupun gambar yang berhubungan pada fokus penelitian.

3. Studi Dokumentasi dibagi atas dokumen pribadi dan dokumen resmi. Dokumen pribadi merupakan catatan atau karangan seseorang secara tertulis mengenai tindakan, pengalaman, maupun kepercayaannya (Moleong, 2000). Sedangkan pada dokumen resmi terbagi atas dokumen internal dan dokumen eksternal. Pada penelitian ini dilakukan studi dokumentasi internal yang berisi laporan kegiatan-kegiatan penanganan bencana alam yang ada di Propinsi Lampung.

\section{HASIL DAN PEMBAHASAN Strategi Sebuah Konsepsi}

Menurut (Majid, 2013) Istilah strategi (strategy) berasal dari "kata benda" dan "kata kerja" dalam bahasa Yunani. Sebagai kata benda, strategos merupakan gabungan dari kata stratos (militer) dengan ago (memimpin). Sebagai kata kerja, strategi berarti merencanakan (to plan actions). Hardy, Langlay \& Rose (dalam Majid, 2013) mengemukakan: "Strategy is perceived as plan or a set of explicit intention preceeding and controlling actions (strategi dipahami sebagai rencana atau kehendak yang mendahului dan mengendalikan kegiatan)". Dalam arti lain, strategi adalah suatu arah serta cakupan jangka panjang sebuah organisasi agar diperoleh suatu keunggulan di dalam lingkungan yang memanfaatkan sumber daya dan kompetensi dengan tujuan memenuhi harapan pemangku kepentingan (stakeholder) (Hutabarat, 2018).

Strategi merupakan salah satu yang penting dan dibutuhkan oleh setiap manusia, baik di dalam organisasi, perusahaan, dan juga pemerintah untuk melakukan tindakan yang terencana dan terarah agar tujuannya dapat tercapai. Hax dan Majluf (dalam Salusu, 2006) merumuskan secara komprehensif mengenai strategi antara lain:

1. Strategi merupakan suatu pola keputusan yang menyatu, konsisten, dan integral;

2. Menentukan serta menampilkan tujuan organisasi yang dibuat dalam bentuk sasaran jangka panjang, program kerja, dan prioritas penggunaan alokasi sumber daya;

3. Menyeleksi suatu bidang yang akan digeluti oleh organisasi;

4. Memberikan respon yang tepat terhadap peluang maupun ancaman yang datang dari lingkungan eksternal organisasi serta mengidentifikasi kekuatan dan kelemahannya; 
5. Melibatkan semua perangkat dan hierarki dari organisasi.

\section{Strategi Korem dalam Penanggulangan Bencana}

Strategi penanggulangan bencana merupakan suatu rencana kegiatan yang dibuat dengan memanfaatkan sumber daya dengan tujuan penanganan bencana dapat berjalan dengan efektif dan efisien (Hediarto, Armawi \& Martono, 2016). Strategi ini memanfaatkan potensi yang ada baik sumber daya manusia maupun sarana dan prasarana yang dimiliki. Dalam hal ini, Komando Resor Militer 043/ Garuda Hitam menggunakan strategi yang melingkupi koordinasi, komunikasi dan pembinaan teritorial (binter) dengan harapan pelaksanaan penanggulangan bencana di Propinsi Lampung berjalan dengan efektif dan efisien.

Koordinasi. Menurut Robinson (2011) yang dimaksud dengan koordinasi adalah integrasi dari kegiatan-kegiatan individual dan unit-unit ke dalam satu usaha bersama yaitu bekerja ke arah tujuan bersama. Sedangkan menurut Handoko (2009) koordinasi adalah proses pengintegrasian tujuan-tujuan dan kegiatan-kegiatan pada satuan-satuan yang terpisah (departemen atau bidang-bidang fungsional) suatu organisasi untuk mencapai tujuan organisasi secara efisien. Dari pendapat tersebut, dapat dipahami bahwa koordinasi merupakan pelaksanaan kegiatan-kegiatan yang mempunyai tujuan bersama yang menjadi sasaran dari kegiatan tersebut. Menurut Handaningrat (dalam Debrilianawati, Saleh \& Hadi, 2013), koordinasi terbagi dua yaitu koordinasi internal yang terdiri dari koordinasi vertikal, koordinasi horizontal, dan koordinasi diagonal, dan koordinasi eksternal yang termasuk koordinasi fungsional.

Pada pelaksanaan penanggulangan bencana, Komando Resor Militer 043/ Garuda Hitam melakukan koordinasi dengan dengan semua stakeholder baik dari Pemerintah Daerah maupun instansi dan organisasi masyarakat lainnya. Koordinasi dilakukan secara intensif terkait informasi mengenai bencana dan cara penanggulangannya. Dalam pelaksanaannya, koordinasi dilakukan secara lintas sektoral dengan melibatkan akademisi dan media. Rapat-rapat koordinasi dilakukan secara rutin untuk menyamakan persepsi dalam penanggulangan bencana sesuai dengan jenis bencana yang ada di Propinsi Lampung.

Rapat Koordinasi yang dilakukan membahas mengenai bencana alam yang faktual dan cara antisipasi terhadap bencana yang kemungkinan terjadi. Rapat Koordinasi ini mempertimbangkan segala aspek bencana alam yang ada di Propinsi Lampung dan membuat rumusan mengenai penanggulangan terhadap bencana alam dengan menyesuaikan terhadap regulasi-regulasi yang ada. Rumusan ini menjadi kesepakatan bersama stakeholder yang terlibat dalam penanggulangan bencana sesuai dengan tugas dan fungsi dari masingmasing stakeholder. Rumusan ini menyangkut cara bertindak dengan SOP yang telah disesuaikan dengan regulasi yang ada terkait penanggulangan bencana alam. Dengan adanya rumusan bersama ini diharapkan penanggulangan bencana alam dapat dilakukan secara terstruktur sehingga pelaksanaannya dapat berjalan secara efektif dan efisien.

Komunikasi. Istilah komunikasi berasal dari Bahasa Latin communicare yang memiliki arti memberitahukan atau membuat sama. Dengan demikian, dalam proses komunikasi harus memiliki unsur kesamaan arti dan makna antara pemberi pesan (komunikator) dan penerima pesan (komunikan) sehingga proses pertukaran pikiran dapat dimengerti bersama. Dengan kata lain proses komunikasi dapat dimaknai sebagai suatu transfer informasi (pesan) dari pemberi pesan (komunikator) dan penerima pesan (komunikan) dengan tujuan mencapai saling pengertian antar kedua belah pihak (Nurhadi \& Kurniawan, 2017). Menurut Effendy (2006) komunikasi dapat didefinisikan proses penyampaian pesan oleh seseorang kepada orang lain untuk memberitahu, mengubah sikap, pendapat, atau perilaku, baik secara lisan (langsung) ataupun tidak langsung (melalui media).

Pada penanggulangan bencana alam, Komando Resor Militer 043/ Garuda Hitam membuat jaring komunikasi yang terhubung ke semua stakeholder yang terlibat pada penanganan bencana alam. Jaring komunikasi tersebut dibuat untuk memudahkan penyampaian berupa informasi ataupun gagasan yang berkaitan dengan bencana alam. Dengan kata lain, semakin cepat proses penyampaian informasi ataupun gagasan 
semakin cepat respon terhadap permasalahan yang sedang dihadapi.

Untuk memudahkan komunikasi baik secara individu maupun kelompok Komando Resor Militer 043/ Garuda Hitam memanfaatkan sarana komunikasi melalui media sosial berupa Facebook, Twitter dan juga Whatsapp Group untuk memudahkan komunikasi. Media sosial saat ini telah menjadi saran yang sangat penting dalam akses penyampaian informasi. Semakin berkembangnya teknologi, akses informasi yang termuat di media sosial menjadi lebih cepat dan tersebar secara massive. Sehingga dengan memanfaatkan media sosial ini, penyampaian informasi maupun gagasan dapat lebih cepat, efektif dan efisien.

Selain itu, Komando Resor Militer 043/ Garuda Hitam bersama stakeholder penanggulangan bencana membuat jaring komunikasi dengan memanfaatkan perangkat komunikasi radio dengan frekuensi yang telah disepakati bersama. Jaring komunikasi radio ini dibuat untuk mengantisipasi jaringan selular yang lumpuh pada saat terjadi bencana alam ataupun dalam kondisi tertentu. Sehingga, komunikasi yang dilakukan oleh Korem bersama stakeholder penanggulangan bencana alam dapat terus terjalin dengan baik. Perangkat komunikasi radio ini lebih praktis dan dinamis dalam penggunaannya di lapangan dan dapat menjangkau ke daerah yang terdalam.

Pembinaan Teritorial (Binter). Pembinaan Teritorial (Binter) merujuk pada Buku Petunjuk Induk Binter Nomor Perkasad/106/XII/2011 tanggal 7 Desember 2011. Di dalamnya dipahami bahwa Binter TNI AD merupakan istilah teknis kemiliteran yang mempunyai arti upaya, pekerjaan, dan tindakan, baik secara berdiri sendiri atau bersama dengan aparat terkait dan komponen bangsa lainnya untuk membantu pemerintah dalam menyiapkan kekuatan pertahanan aspek darat yang meliputi wilayah pertahanan dan kekuatan pendukungnya serta terwujudnya kemanunggalan TNI-Rakyat, yang dilaksanakan sesuai kewenangan dan peraturan perundang-undangan dalam rangka tercapainya tugas pokok TNI AD. Dapat diartikan, Binter TNI AD adalah kegiatan TNI $\mathrm{AD}$ dalam menjalin dan membina hubungan dengan seluruh komponen masyarakat agar dapat digunakan untuk kepentingan pertahanan daerah. Selain itu, Binter TNI AD dilakukan melalui pendekatan dan metode pembinaan dari aspek ketahanan wilayah, komunikasi sosial, dan bakti TNI untuk mendukung proses pembangunan daerah (Herdiansah, Ummah, \& Simanjuntak, 2017). Kegiatan Binter TNI AD di daerah dilaksanakan oleh Korem beserta jajarannya di wilayahnya masing-masing.

Dalam penanggulangan bencana alam, Binter TNI AD memiliki peranan yang cukup penting dalam kesiapan dan respon menghadapi bencana alam (Fauzi, Nurdin R \& Nurdin, 2014). Kegiatan Binter ini dilaksanakan oleh Korem 043/Gatam sebagai salah satu strategi untuk menghadapi bencana alam yang terjadi di Wilayah Propinsi Lampung. Adapun strategi Binter yang dilaksanakan terkait penanggulangan bencana alam menyangkut 3 (tiga) tahapan yaitu pada prabencana, tanggap darurat dan pascabencana. Berikut strategi yang dilaksanakan antara lain :

Pertama, strategi pada pra bencana yaitu dengan kegiatan seperti: (a) Memberikan sosialisasi kepada masyarakat mengenai jenisjenis bencana alam, bahaya serta langkahlangkah untuk mengantisipasi jika bencana yang terjadi di wilayahnya masing-masing; (b) Membuat Early Warning System secara sederhana dengan memanfaatkan potensi yang ada di daerahnya agar bencana alam dapat dideteksi lebih awal. Sebagai contoh dengan memanfaatkan TOA masjid atau kentongan untuk memberikan informasi kepada masyarakat terkait bencana alam; (c) Membuat titik kumpul untuk memberikan petunjuk kepada masyarakat tempat kumpul yang aman jika terjadi bencana alam; (d) Mengajak dan menggerakkan masyarakat untuk lebih peduli terhadap lingkungan. Implementasi dari peduli lingkungan tersebut yaitu dengan membuang sampah pada tempatnya dan melakukan penghijauan melibatkan masyarakat; (e) Menginisiasi pembentukan kelompok relawan seperti tagana atau organisasi relawan lainnya ditiap desa dengan pendampingan berupa pembinaan maupun pelatihan oleh jajaran Korem di desa.

Kedua, strategi pada tanggap darurat yaitu dengan kegiatan seperti : (a) Ikut serta membantu pencarian dan pertolongan terhadap korban untuk dievakuasi ke tempat 
yang aman dan mendapat perawatan lebih lanjut dari tenaga medis; (b) Membantu memperbaiki Infrastruktur Vital yang rusak dengan memanfaatkan peralatan yang dimiliki dan juga berkoordinasi dengan stakeholder lainnya untuk mendukung peralatan yang dibutuhkan; (c) Mendirikan dapur umum untuk para pengungsi maupun relawan yang terlibat pada tanggap darurat dengan memanfaatkan peralatan, sarana dan prasarana yang dimiliki; (d) Membantu menyalurkan bantuan baik berupa bantuan barang, uang, makanan/bahan makanan ataupun bantuan lainnya kepada korban atau masyarakat yang membutuhkan di daerah bencana. Selain itu, bantuan keamanan dalam penyaluran bantuan agar tepat sasaran dan meminimalisir terjadinya penyimpangan bantuan; (e) Berkoordinasi dengan Pemda untuk menyiapkan kantung-kantung pengungsian dengan memanfaatkan sarana serta prasarana yang ada di sekitar wilayah terjadinya bencana alam.

Ketiga, strategi pada pascabencana yaitu dengan kegiatan seperti: (a) Membantu memperbaiki sarana dan prasarana yang rusak agar dapat digunakan kembali oleh masyarakat. Selain itu, membuat hunian sementara untuk korban yang rumahnya terdampak bencana alam; (b) Berkoordinasi dengan Pemda dan juga Rumah Sakit untuk menyediakan tenaga medis. Tenaga medis tersebut dibutuhkan untuk memberikan pengobatan kepada masyarakat yang terdampak bencana alam; (c) Membantu penyiapan tenaga psikiater sebagai bagian dalam trauma healing kepada masyarakat yang terdampak bencana alam; (d) Membantu penyiapan tenaga pengajar untuk anak-anak yang terdampak bencana alam sehingga tidak terputus proses belajar dan mengajar disekolah; (e) Mengadakan kegiatan yang membangkitkan moral dan menghibur kepada masyarakat yang terdampak bencana alam.

\section{SIMPULAN}

Keterlibatan TNI dalam penanggulangan bencana alam merupakan bentuk dari pelaksanaan tugas dan fungsi TNI yaitu Operasi Militer Selain Perang (OMSP) yang telah diamanatkan di dalam Undang-Undang Republik Indonesia Nomor 34 tahun 2004 tentang TNI. Dengan militansi dan jumlah anggota yang tersebar di seluruh wilayah
Indonesia menjadi ujung tombak dalam membantu Pemerintah Daerah dalam penanggulangan bencana alam di daerah. Pelaksanaan keterlibatan TNI di daerah di jalankan oleh Korem sebagai penanggung jawab wilayah terkait dengan pertahanan daerah. Komando Resor Militer 043/ Garuda Hitam yang bertanggung jawab di wilayah Propinsi Lampung menjalankan tugas dan fungsinya terkait dengan penanggulangan bencana alam bekerjasama dengan stakeholder lainnya. Beberapa strategi dibuat dan dilaksanakan oleh Komando Resor Militer 043/ Garuda Hitam melibatkan stakeholder penanggulangan bencana alam dalam rangka antisipasi dan meningkatkan respon terhadap bencana alam yang ada di Propinsi Lampung. Strategi-strategi penanggulangan bencana yang dibuat menyesuaikan dengan tahapan dari penanggulangan bencana alam yaitu prabencana, tanggap darurat dan pasca bencana.

Dalam penanggulangan bencana alam didaerah dibutuhkan kerjasama oleh berbagai sektor atau stakeholder yang memiliki tugas dan fungsi penanggulangan bencana alam. Komunikasi dan koordinasi harus dilakukan secara intensive oleh semua pihak agar pelaksanaan penanggulangan bencana dapat berjalan dengan efektif dan efisien. Selain itu, harmonisasi terhadap regulasi-regulasi yang terkait penanggulangan bencana alam agar tidak terjadi tumpang tindih tugas dan fungsi sehingga pada pelaksanaannya mengacu pada SOP yang ada.

Proses penanggulangan becana alam ini juga melibatkan peran aktif masyarakat. Keterlibatan masyarakat ini dengan memberikan informasi potensi bencana alam serta langkah-langkah untuk antisipasi terjadinya bencana alam. Dengan melibatkan masyarakat dalam penanggulangan bencana alam akan meningkatkan kesiapan masyarakat menghadapi bencana alam di daerahnya masing-masing. Selain itu, masyarakat akan lebih peduli terhadap lingkungan sehingga masyarakat akan menjaga alam agar tidak rusak.

\section{DAFTAR PUSTAKA}

Budi, S. (2012). Komunikasi Bencana: Aspek Sistem (Koordinasi, Informasi dan Kerjasama). Jurnal Komunikasi, 1(4): 363-372, 
http://dx.doi.org/10.24329/aspikom.v1i4.3 6.

Debrilianawati W., D., Saleh, C. \& Hadi, M. (2013). Peran dan Koordinasi Antar Instansi Dalam Pemberdayaan Warga Binaan Permasyarakatan di Lembaga Permasyarakatan (Studi tentang Program Kemandirian Pelatihan Kerja Pengelolaan Ikan Air Tawar di Lembaga Pemasyarakatan Kelas IIB Kota Pasuruan. Jurnal Administrasi Publik, 1(2): 174-180.

Effendy, O. U. (2006). Ilmu Komunikasi: Teori dan Praktek. Bandung: Remaja Rosdakarya.

Fauzi, L.M., Nurdin R, A. \& Nurdin, I. (2014). Peran Tentara Nasional Indonesia dalam Penanggulangan Bencana di Daerah Istimewa Yogyakarta. Jurnal Ilmu Politik dan Komunikasi, 4(2): 127-135.

Handoko, H. (2009). Manajemen. Jakarta: BPFE dan LMP2M-YKPN.

Hediarto, I., Armawi, A. \& Martono, E. (2016). Optimalisasi Peran Kodim dalam Penanggulangan Tanggap Darurat Bencana Alam dan Implikasinya Terhadap Ketahanan Wilayah (Studi di Kodim 0613/ Ciamis, Jawa Barat). Jurnal Ketahanan Nasional, 22(3): 321-333.

Herdiansah, A.G., Ummah, K.C. \& Simanjuntak, S. (2017). Peran dan Fungsi Pembinaan Teritorial TNI AD Dalam Perbantuan Pemerintah Daerah: Studi di Kabupaten Lebak. Jurnal Ilmu Pemerintahan Cosmogov, 3(1): $65-82$ https://doi.org/10.24198/cosmogov.v3i1.12 638.
Hutabarat, J. (2018). Strategi: Terpadu, Komprehensif, Simultan. Jakarta: Prasetiya Mulya.

Majid, A. (2013). Strategi Pembelajaran. Bandung: Remaja Rosdakarya.

Moleong, L. J. (2000). Metode Penelitian Kualitatif. Bandung: Remaja Rosdakarya.

Nurhadi, Z.F. \& Kurniawan, A.W. (2017). Kajian Tentang Efektivitas Pesan dalam Komunikasi. Jurnal Komunikasi Hasil Pemikiran dan Penelitian, 3(1): 90-95.

Patria, R.N. (2013). Kapasitas TNI AD dalam Penanggulangan Bencana (Studi Kasus Kapasitas Kodim 0505/ Jakarta Timur dalam Penanggulangan Bencana Banjir. Jurnal Pertahanan dan Bela Negara, 3(1): 157-182.

Petunjuk Induk (Bujukin) Binter Nomor Perkasad/106/XII/2011 tanggal 7 Desember 2011.

Pusat Studi Gempa Nasional. (2017). Peta Sumber dan Bahaya Gempa Indonesia Tahun 2017.

Robinson, J. P. (2011). Strategic Management: Formulation, Implementation and Control, Twelfth Edition. New York: Mc Graw Hill.

Salusu, J. (2006). Pengambilan Keputusan Strategik Untuk Organisasi Publik dan Organisasi Non Profit. Jakarta: Grasindo.

Syamsuddin, L. (2009). Manajemen Keuangan Perusahaan. Jakarta: PT. Raja Grafindo Persada.

Undang-Undang RI Nomor 34 Tahun 2004 tentang Tentara Nasional Indonesia (TNI). 